\title{
Music and Gymnastic harmonization under the viewpoint of the platonic meaning of life
}

\author{
Konstantina Gongakia, Stavros Kapranos ${ }^{b}$
}

\section{Summary}

The essence of life according to Plato is summed up in the tendency of every living being to protect itself and its species from death, by searching immortality. This pursuit is achieved either by reproduction or by intellectual creation. In order for the soul to conquer the existence which will be worthy of man, it must separate from the mortal body. The highest goal of philosophical education is the soul to be led to the view of the idea of the good (agatho), which is the foundation of all knowledge. Thereunto, specific courses are proposed, Music, Gymnastics, Mathematics and Dialectics. Music is preceded temporal and absolute by gymnastics. The school of Pythagoras was the first to put the music-soul relationship, in the service of upbringing and mental physique.

Plato attempts to establish man's tendency for rhythm and movement in nature and in the gods. At the same time, he emphasizes the balance between mental and physical education, in order to form the right ethos. For the best fulfillment of these terms, the two superior parts of the soul must be properly trained, the logical with music and the thymoides with gymnastics. The symmetrical movement of the body is ensured by exercise, while for the soul, music and philosophy are used. This targeted intervention will lead them to a harmonious connection. Moreover, it should be ensured that the movements are symmetrical with each other. This is the real goodness (kalokagathia). The unilateral cultivation of gymnastics at the expense of music is considered the main cause of the decline of the excellent republic and the decadence in oligarchy, in the regimein which the morality is imposed by violent, uneducated people who will have neglected the real Muse, the one who is accompanied by the logic and philosophy.

Keywords: Plato, Music, Gymnastics, harmony, symmetry, immortality, philosophical education, idea of the good, ethos, Muse, soul, body.

Plato, seeking the meaning of life, ${ }^{1}$ claims that its definite purpose is the actualization of the divine principle in man, or, in other words, human's effort to achieve that benevolent existence upon

a. School of Physical Education and Sport Science, National and Kapodistrian University of Athens.kgogaki@phed.uoa.gr

b. School of Physical Education and Sport Science, National and Kapodistrian University of Athens.

1. Evgenij N. Trubeckoj, 1999. The social utopia of Plato, transl. Dimitrios V. Triantaphyllidis - Dina Samothraki, Athens, publ. Mouses - Armos, p. 15. which nor time nor death exert any authority. The ultimate (highest) goal is the immortality as human perpetuation in god, and this goal constitutes the insuperable precondition of the entire life, as Evgenij Trubeckoj notices. ${ }^{2}$ The evidence of human immortality which attempts Plato, according to Eduard Zeller ${ }^{3}$ and other scholars, result to the same point: The soul, as existence and as conception, is indissolubly connected to life, it is substantially inseparable from life. In other words, the soul

2. Op. cit. 17.

3. Eduard Zeller, Die Philosophie der Griechen in ihrer geschichtlichen Entwicklung B. II, I Abth, 697. 
-according to its nature - is as incompatible with death as life itself. ${ }^{4}$

The process of life is consisted of constantly alternating births and deaths, or, else, of "an alternation of rehabilitation and perdition", as it is defined nowadays. The human existence is preserved by replacing the old and the lost with an identical new one. ${ }^{5}$ The mortal nature's pursuit of eternity and immortality is achieved through reproduction, given that, in this way, one leaves something else behind him, something new. ${ }^{6}$ According to Plato, the essence of life is condensed in every living existence's tendency to preserve itself and its kind from death by the quest of immortality. One cannot find this so clearly nowhere else but in love (eros), whose elementary form is the physical attraction, where the earthly existence is at its efflorescence peak. ${ }^{7}$ Man does not only aim for the physical, but also for the spiritual birth. ${ }^{8}$ On the basis of both these aims lies the same love passion for immortality.

Apart from those who seek for the immortality in childbearing, aiming in this way to ensure in the future a happy memory, there also exist those who are fascinated by spiritual birth, creation, immortal glory, post-mortem fame, ${ }^{9}$ trying to perpetuate their existence by using everything befitting it. ${ }^{10}$ Wisdom and every virtue are the qualities that fit properly to the value of the spirit. Parents of these intellectual people are the poets and the artists, the state founders and the truth preachers. When someone has preserved these values -since his youth- and possesses a divine nature, then, when his time comes, he turns his eyes and seeks for the beautiful, in order to give birth to these values.

4. Plato, Phaedo 105c-e. Cf. Trubeckoj, p. 17.

5. Plato, Symposium 207d, 208c-b, Laws 721c. Cf. Trubeckoj, p. 18.

6. Plato, Symposium 207d, 208c-b. Cf. Trubeckoj, p. 19.

7. Plato, Symposium 206c. Cf. Trubeckoj, p. 20. For the platonic eros see more G.R.F. (John) Ferrari, 1992, "Platonic love», in: Richard Kraut (ed.), The Cambridge Companion to Plato, publ. Cambridge University Press, pp. 248-276.

8. Plato, Symposium 206b. Cf. Trubeckoj, p. 21.

9. Plato, Symposium 201a.

10. Ibid, 208c-e.
It is obvious that such a man will never give birth to ugliness. ${ }^{11}$ People who are gifted of this virtue are attracted by the beautiful bodies as well as by the beautiful souls. And when they find the object of their quests, namely the people who combine both these beauties, the courtesy and the natural gifts, then they give birth to the great beauty (kallos) in them.

All the people seek for and fall in love with the beautiful and the good (agathon). That is why love must be the love of the great beauty (kallos), ${ }^{12}$ or else, it must be love of the everlasting possession of the good. However, the majority, during their quest, go out of their way and they are attached to the image of the great beauty (kallos), instead of the great beauty (kallos) itself, to the image of the good, instead of the good itself. But the purpose of love, according to Plato, is the absolute beauty and the absolute goodness, which however, do not fit in the border of the finite earth reality. The soul, in order to conquer this very existence which will be worthy of the human being, must be separated from the body. The route to true life, the life of goodness, passes through death. The meaning of life is the knowledge, the true philosophy, which is nothing else but a study of death. ${ }^{13}$ The true philosopher, the virtuous man is distinguished from the rest of the mortals exactly because he wishes to liberate his soul from its corporal bonds. He seeks the wisdom, but his body acts as a restraining factor during this search, for his senses mislead him unceasingly. The soul does not conceive the truth through the experience of the senses but through the meditation. The soul functions better only when it is not prevented by the pleasure, by the passion, in other words, when it becomes independent of the carnal element. The more the soul is liberated from its relation to the body, the more it turns towards the Idea and the real existence. ${ }^{14}$

11. Ibid, 208b. Cf. Trubeckoj, p. 22.

12. Plato, Symposium 201a. Cf. Trubeckoj, p. 24. 13. Plato, Phaedo 64a ff. Cf. Trubeckoj, p. 27.

14. Plato, Phaedo 65a. Cf. Trubeckoj, op. cit. For the theory of Ideas in Plato see more William K. C. Guthrie, 1987 2nd, The Greek Philosophers. From Thales to Aristotle, transl. Ant. I. Sakellariou, publ. Dim. N. Papadima, Athens, 
The true, the good, ${ }^{15}$ the just, the great beauty (kallos) are understood with the help of the spiritual eyes, the soul. The more one approaches the knowledge, the more he renounces his body. According to Plato, the complete knowledge becomes possible for the human being, only after his complete separation from the body, that is after his death, after his liberation from the carnal bonds. ${ }^{16}$ The ultimate purpose of the philosophical education is the guidance of the soul to the view of the idea of the good, which consists the foundation of justice ${ }^{17}$ and other ideas, the foundation of every virtue, usefulness and use. ${ }^{18}$ However, in order to reach this view, one leads his soul with lessons, which aim at the gradual distancing from the perceptible world and at the approach of the conceivable. For this purpose, specific courses are proposed, namely Music, Gymnastic, Mathematics and Dialectic, which is the culmination, the crowning of the courses. ${ }^{19}$

Music has a broad meaning in the ancient world, including usually poetry and melody. Sometimes, however, it includes everything that is mentioned in the Muses, that is, almost all of the arts. ${ }^{20}$

pp. 83-100. Title of the Prototype: The Greek Philosophers: From Thales to Aristotle, Routledge Classics, Methnen and Co. Ltd, London, 1950, 1984 4th. See also Ioannis N. Theodorakopoulos, 1947, "The theory of the idea", in: I. $\mathrm{N}$. Theodorakopoulos, Introduction to Plato, in Athens, pp. 159-213.

15. For the recognition of good see Robin Barrow, 1976, Plato and Education, London and Boston: Routledge and Kegal Paul, pp. 69-70, 53.

16. Plato, Phaedo 65a, 65c, 66a, 66e, 67a, 67b. Cf. Trubeckoj, p. 28.

17 Richard Kraut, 1992, «The defense of justice in Plato's Republic», in: R. Kraut, op. cit. pp. 311-337.

18. Plato, Republic F 508e, Z 517c, F 505a. Cf. Andreas Manos, 2007. "The Good as the top of Ideas and the Unwritten Doctrines", in: A. Manos, Platonic Philosophy. A sacred tetractis of questions, publ. Kastaniotis, Athens, pp. 4163. Cf. also Tasos Arvanitakis, Plato. As far as the movement, publ. Zitros-Skepsis, p. 203. 19. Plato, Republic Z 534e.

20. Cf. Arvanitakis, p. 228.
What is harmony, rhythm and measure is already known to us by Philebus. ${ }^{21}$ In Laws "rhythm and harmony is called the sense of classes in motion". ${ }^{22}$ Nature, as a divine creation, has harmony and rhythm. The nature and the motion of the celestial bodies are characterized by harmony, and the gods have placed the rhythm in the human being. ${ }^{23}$ Plato in Laws seeks the common origin and the principles of gymnastic, music and dance. He attempts to establish chorea and generally the tendency of man to pace and move in nature, in the physiology of man. ${ }^{24}$ Since nature endowed man with the movement and the voice, and the gods gifted - exclusively to man - the sense of rhythm and harmony, therefore the one is gift from nature and the other one gift from the gods, more specifically the gods are the Muses and Apollo. ${ }^{25}$

The effect of Music on man is very strong, so that it reaches the depths of the soul. For this reason, in order to control the mood of citizens as well, the ruler of the city himself has to determine the content of the music. According to the platonic system, melodies that are mournful or melancholic, corrupt and generally provoke the senses, and therefore should not be tolerated. On the contrary, the desired forms of melodies are defined, namely: melodies full of awe and piety, pleading melodies as well as teaching, martial, and modest melodies, all the forms of melody that correspond to the basic virtues. ${ }^{26}$ Plato, convinced of the moral power of music, attributes an important role to it, considering that the willful melodies have no place in the philosophers'republic. ${ }^{27}$ The "loose" melodies are not allowed. Approved harmonies are only those that fit into "martial men", namely the "Doric" and the "Frygian". In addition, the freedom in the use of measures is not allowed, the only measures allowed are those who fit the "decent and brave man". Besides, Plato even determines the type of musical instruments. Multi-string instruments, e.g.

21. Plato, Philebus 17c-d.

22. Plato, Laws B 653e.

23. Ibid B 654a. Cf. Arvanitakis, p. 225, 229.

24. Plato, Laws B 653d. Cf. Arvanitakis, p. 227. 25. Plato, Laws B 654a. Cf. Arvanitakis, op. cit. 26. Plato, Republic C 398d-399e.

27. Ibid, C 398d. 
the pipe, which can produce any kind of melody, are forbidden. In the platonic city, only Apollo with the lyre and the guitar can remain, as well as the shepherds with one more instrument, the syringe. Art in all its forms, especially as reason and as music, has a purifying effect on the soul. ${ }^{28}$ By determining the allowed rhythms, "katharsis" of the city reaches its end. Plato, generally, condemns the variety, whether in music or gymnastic, or even in the

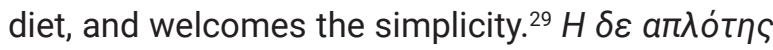

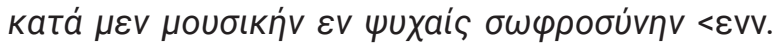

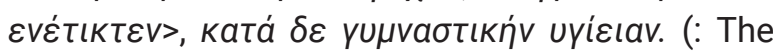
simplicity in music gives birth to prudence in the soul, similarly, in gymnastics it gives birth to the health of the body).

The ascetic ideal of The Republic promotes, thus, certain requirements in Music, as well as in painting, sculpture and architecture. The elements that are distinguished for their ugliness, arrhythmia and inappropriateness have to be eliminated from all types of art. ${ }^{30}$ The same ascetic mood characterizes Plato's thoughts in gymnastic. The term "gymnastic" signifies on the one hand the systematic movement which aims at health, beauty (kallos) and on the other hand the physical exercise, which results in performing better the tasks that require skill and power, such as martial arts, or grace, such as dance. ${ }^{31}$ Plato considers gymnastic, along with art, as one of the most important means of education, arguing that gymnastic benefits the soul rather than the body. Art, alone, without gymnastic, strains the soul. On the contrary, gymnastic alone, without art, turns the soul hard and vulgar.

The purpose of this kind of education, namely the combination of music and gymnastic, is the

28. Plato, Laws B 659e, 665e-666c.

29. Plato, Republic C 404e. Cf. Arvanitakis, p. 271.

30. Plato, Republic C 401d. Cf. Trubeckoj, p. 145. For the scene of the Republic see Walter Pater, 1969, Plato and Platonism; a series of lectures, New York, Greenwood Press, (1893 1st), pp. 236-237.

31. See more Konstantina Gongaki, 2003. "The instruction (teaching/meaning) of Gymnastics according to Plato", in: K. Gongaki, The perceptions of ancient Greeks about Athletics, Typothito - G. Dardanos, Athens, pp. 125-141. achievement of the "measure" between these two extremes, as well as the creation of a harmonious and moderate spiritual temperament. Plato points out that music - art, in general - should not aim at the pleasure but at the moral improvement, ${ }^{32}$ so the criteria for it must be strictly moral. Art is an imitation (mimisis) of manners and customs, and those who mime, as well as those who watch them, are ultimately influenced by the ethics that the imitation expresses. Therefore, art must only imitate good ethics, in order to benefit the excellent city. ${ }^{33}$

Plato, as already has been mentioned, considers that the nature and the movements of the celestial bodies are characterized by harmony, and that the gods have placed the rhythm in the human being. ${ }^{34}$ In Theaetetus ${ }^{35}$ motion is recognized as the most universal phenomenon. Motion created life itself. Or, else, the movement of living organisms is the result of the universal movement that governs the universe. The physical habit (exis) is destroyed by the inactivity and the leisure but "it is saved by the exercises and the movements" . ${ }^{36}$ Similarly, the lack of the required education and the ignorance on the one hand, and the lessons on the other, affect the habit of the soul. ${ }^{37}$ The same applies to the whole universe and all the beings. As long as they perform their movements they exist and they escape the degeneration. But once they stand, then everything will be disturbed..$^{38}$ Movement is the principle on which all life depends, and there is nothing beyond it. ${ }^{39}$ External motion is also useful for the child's mental peace, because it compensates and neutralizes the internal "manic",

32. Plato, Republic, Books B and C. See more: Julius Moravcsik, 2000, Plato and Platonism: Plato's Conception of Appearance and Reality in Ontology, Epistemology, and Ethics, and Its Modern Echoes, Oxford, Cambridge (USA), Blackwell.

33. Cf. Arvanitakis, p. 234

34. Plato, Laws B 653c-d, 654a. Cf. Arvanitakis, p. 229.

35. Plato, Theaetetus 152c.

36. Ibid, 153b.

37. Ibid, 153c. Cf. Arvanitakis, p.268.

38. Plato, Theaetetus 153d.

39. Ibid, 156a. 
unruly movements. ${ }^{40}$ Plato looks for the nature in all manifestations of life, especially in the area of biology. ${ }^{41}$

In respect to the human being, the superior part of the soul is governed by a principle of smooth movements, determined by mathematical terms. This is a principle full of order and beauty. On the contrary, inferior souls experience dark and rough physiological functions. Beauty and harmony seem to be absent. The sorrows, the joys, the carnal desire, etc. prevent man from following the reason (logos) that characterizes the superior soul. When, however, a strong soul lives in a weak body or, on the contrary, when a strong body is guided by a weak mind, then, in these cases, it occurs inevitably an asymmetry of a specific form. There is only one salvation for these two unhealthy conditions: the simultaneous body and soul exercise. This is the only way to achieve balance and health. The symmetrical movement of the body is ensured by the exercise (gymnastic), while for the soul cultivation one will use music and philosophy. At the same time, one must make sure that the movements are symmetrical with each other. This is the real goodness (kalokagathia). ${ }^{42}$

Music, given the content above, precedes the gymnastic in time and in every other aspect. Plato's dominant idea is that a body in good shape cannot benefit the soul only because of this, but an exceptional spirit can benefit the body. ${ }^{43}$ In the Republic, music, just like rhythm and harmony, submits to the same rules and has a determinant significance. The Pythagoras Academy was the one who first set the relationship between music and soul in the service of upbringing and soul education. According to Pythagoras' basic theory, man is physically and mentally defined by harmony and number, as the whole world is "harmony and number". ${ }^{4}$ Plato emphasizes the balance

40. Cf. Arvanitakis, p.269.

41. Plato, Laws F 775c-d.

42. Plato, Timaeus $87 c-88 c$. Cf. Arvanitakis, pp. 272-273.

43. Plato, Republic C 403d. Cf. Richard F. Stalley, 1983, An Introduction to Plato's Laws, Oxford, publ. Basil Blackwell, p. 130.

44. Annemarie Jeanette Neubecker, 1986, Mu- between mental and physical education in order to form the right ethos, while, at the same time, points out the value of prudence. ${ }^{45}$ Young people's education by accepting a strict regulatory context governs everything. All the institutions of the ideal city, that refer to education, seem to have been created to eliminate the individuality. A great importance is given in warriors' exercises, especially in the military ones, given the war ideals of this era. ${ }^{46}$ But while the warriors' exercises are of particular importance, however, Muse is always superior to gymnastic, for the martial customs' appeasement by the Muses is the ultimate purpose of Plato's vision. ${ }^{47}$

In The Republic Plato refers to the existence of two crucial aspects of character, one that develops through physical training and one that develops through music, that is, the "arts education". ${ }^{48}$ He emphasizes on the balance between mental and physical education in order to form the right morals (ethos), while he points out that prudence is necessary. ${ }^{49} \mathrm{He}$ claims that those who devote all their time to sports, become rude and boring, while those who completely neglect them end up incapable of action.

Gymnastic, indirectly, but undoubtedly, helps the spirit in its enforcement over the undisciplined appetitive (epithymitiko). The desirable soul is the soul of impulses, needs and desires. ${ }^{50}$ It is the soul who falls in love, who feels hunger and thirst, the soul is scattered around many desires constantly. ${ }^{51}$ According to the platonic theory, the leading

sic in Ancient Greece, transl. Mirella Simota Fidetzi, publ. Odysseas, Athens, p. 136.

45. Plato, Republic C 401a, 410c, 412a.

46. Ibid, H 547d. Cf. Trubeckoj, p. 165.

47. Cf. Trubeckoj, p. 183.

48. Plato, Republic C 410a-412e.

49. Ibid, 401a ff, 410e, 412a.

50. The affect (thymiko) part of the soul according to Plato resides in the heart, while the appetitive (epithymetiko) part resides between the abdomen and the diaphragm, see more Evaggelos Moutsopoulos, 1974, The path of the spirit, The beings, publ. Ermis, Athens, p. 203. 51. Plato, Republic D 439d. Cf. Abel Jeannière, 2008, Plato, transl. Stavros Vlontakis, publ. Dim. N. Papadima, 2nd ed., Athens, p. 234. Ti- 
role in complex human nature belongs to the logical (logistiko) while the spirited (thymoides) fits to be its ally. For the complete fulfillment of these conditions, the two higher parts of the soul must be properly educated, the logical through music and the spirited through gymnastic. This targeted intervention will lead the logical and the spirited to an agreement: music and gymnastic conflation will make them consistent. ${ }^{52}$ Nevertheless, it is the soul who always directs the gymnastic, not the body. ${ }^{53}$ Everything that concerns the gymnastic will be entrusted to the soul (as a leader) and the intellect, which is a soul trait, for the soul and only the soul has the ability to convey the virtue to the body. The opposite is not true. By the term intellect Plato means science. As a consequence, the gymnastic must be science-based. The soul, the spirit is the one that will determine the rules of gymnastic wisely and under the proper design.

According to Glenn Morrow, this attitude of Plato, of lessening the value of physical activity in some occasions, is not the expression of an intellectual disdain for the one-dimensional physical strength, but a dislike of the professionalism of Greek sports, mainly during the 4 th century. ${ }^{54}$ Moreover, the physical exercise, in which the Republic is interested in, is not addressed to track and field athletes, who aim exclusively at winning. It is absolutely directed to the Guardians' rank, who are in charge of the great but painful task of protecting and saving the city from its enemies. That is why Plato calls the Guardians "athletes of the greatest struggle as well as martial athletes". ${ }^{55}$ The ultimate goal of gymnastic is to strengthen the spirited of the soul, that part of the soul where the prowess is located. In another passage of the Republic, it is underlined that even physical exercise aims for the benefit of the soul, and not for the

tle of Prototype: Platon, Editions du Seuil, avril, 1994.

52. Plato, Republic D 441e-442a.

53. Cf. Arvanitakis, p. 76.

54. See more in Glenn Morrow, 1960, Plato's Cretan City. A Historical Interpretation of the Laws, Princeton University Press, Princeton, New Jersey, p. 332.

55. Plato, Republic C 403e, 404a, 416d, 422b. benefit of the body. ${ }^{56}$

City guardians should combine in the right way the spirited and the "peaceful», the courage and the philosophical mood. He who combines best music and gymnastic, he is entitled to be called the most musical and harmonious. ${ }^{57}$ The gods, according to Plato, gifted man with two arts, music and gymnastic, which aim for the spirited and the wisdom, and it is a man's duty to match these gifts in harmony. ${ }^{58}$ If people fail in this essential pursuit of a balanced cultivation of music and gymnastic, many misfortunes arise for the individual, as well as for the city, which is certainly influenced by people's ethics. The unilateral cultivation of gymnastic at the expense of music is considered to be the main cause of the excellent city's decline. It is also the reason of the regime degradation in oligarchy, where people who are brave but uneducated and vulgar impose their ethics. The education of these people is not based on persuasion but on violence, since the true Muse, the one that accompanies speech and philosophy, is neglected by focusing mainly on physical exercise than on spiritual cultivation..$^{59}$

According to the above, the real balance of human nature is achieved through philosophy and music, which will strengthen the rational part of the soul, as well as through the gymnastic, which will strengthen the body and spirited part of soul, for each section exercises what is intended by its nature to exercise: the reason (logos) to lead and direct the desires of the other parts of the soul. Only then the athletic body becomes an ally of reason in its attempt to subdue the demanding appetitive. If, however, the soul as a whole abandons its guidance to the spirited, then it is dominated by the feeling of honor, and it becomes ambitious and supercilious (high-minded). This negative

56. Ibid, C410c. Cf. Daniel A. Dombrowski, 1979, Plato and Athletics, Journal of the Philosophy of Sport, 6: 29-38.

57. Plato, Republic C 412a. Cf. Arvanitakis, p. 281, George Maximilian Anthony Grube, 1980, Plato's Thought, Indianapolis: Hackett Publishing, 2nd ed., p. 234.

58. Plato, Republic C 411e-412a.

59. Ibid, H 548b-c. See Arvanitakis, p. 282. 
phenomenon occurs only if the person has been unilaterally educated and tends to appreciate gymnastic more than philosophy. ${ }^{60}$

\section{Bibliography}

- Plato: Republic

Laws

Symposium

Timaeus

Theaetetus

Phaedo

Philebus

- Arvanitakis, Tasos, n.d., Plato. As far as the movement, Zitros/Skepsis.

- Gongaki, Konstantina, 2003. "The instruction (teaching/meaning) of Gymnastics according to Plato", in: K. Gongaki, The perceptions of ancient Greeks about Athletics, Typothito-G. Dardanos, Athens, pp. 125-141.

- Guthrie, William K. C., 1987, $2^{\text {nd }}$ ed. The Greek philosophers. From Thales to Aristotle, transl. Ant. I. Sakellariou, Dim. N. Papadima. Title of the Prototype: The Greek Philosophers: From Thales to Aristotle, Routledge Classics, Methnen and Co. Ltd, London, 1950, 1984 4th.

- Theodorakopoulos, Ioannis N., 1947. "The theory of the idea", in: I. N. Theodorakopoulos, Introduction to Plato, Athens, pp. 159-213.

- Jeannière, Abel, 2008. Plato, transl. Stavros Vlontakis, Dim. N. Papadima, 2nd ed., Athens. Title of the Prototype: Platon, Editions du Seuil, avril, 1994.

- Manos, Andreas, 2007. "The Good as the top of Ideas and the Unwritten Doctrines", in: A. Manos, Platonic Philosophy. A sacred tetractis of questions, Kastaniotis, Athens, pp. 41-63.

- Moutsopoulos, Evangelos, 1974. The Path of the Spirit, The Wights, Hermes, Athens.

- Neubecker, Annemarie Jeanette, 1986. Music in Ancient Greece, transl. Mirella Simota - Fidetzi, Odysseas, Athens.

- Trubeckoj, N. Evgenij, 1999. The social utopia of Plato, transl. Dimitrios V. Triantaphyllidis - Dina Samothraki, Mouses-Armos, Athens.
- Barrow, Robin, 1976. Plato and Education, London and Boston: Routledge and Kegal Paul.

- Dombrowski, Daniel A., 1979. Plato and Athletics, Journal of the Philosophy of Sport, 6: 29-38.

Ferrari, G. R. F. (John), 1992. "Platonic love», in: Kraut, Richard (ed.), The Cambridge Companion to Plato, Cambridge University Press, pp. 248-276.

Grube, George Maximilian Anthony, 1980. Plato's Thought, Indianapolis: Hackett Publishing, 2nd ed. Kraut, Richard, 1992. "The defense of justice in Plato's Republic», in: Kraut, Richard (ed.), 1992. The Cambridge Companion to Plato, Cambridge University Press, pp. 311-337.

- Moravcsik, Julius, 2000. Plato and Platonism: Plato's Conception of Appearance and Reality in Ontology, Epistemology, and Ethics, and Its Modern Echoes, Oxford, Cambridge (USA), Blackwell.

- Morrow, Glenn, 1960. Plato's Cretan City. A Historical Interpretation of the Laws, Princeton University Press, Princeton, New Jersey.

- Sayers, Sean, 1999. Plato's Republic. An Introduction, Edinburgh University Press, Edinburgh.

Pater, Walter, 1969. Plato and Platonism; a series of lectures, New York, Greenwood Press, (1893 1st ed.).

- Stalley, Richard F., 1983. An Introduction to Plato's Laws, Oxford, Basil Blackwell.

- Taylor, Alfred Edward, 1937. Plato. The Man and his Work, London: Methuen.

- Zeller, Eduard. Die Philosophie der Griechen in ihrer geschichtlichen Entwicklung B. II, I Abth, 697.

60. See more Arvanitakis, pp. 282-283. 